Canadian University Music Review

Revue de musique des universités canadiennes

\title{
Theory's Children; or, The New Relevance of Musicology
}

\section{Stephen McClatchie}

Volume 21, numéro 1, 2000

Music Studies in the New Millennium : Perspectives from Canada Les études en musique dans le nouveau millénaire : perspectives canadiennes

URI : https://id.erudit.org/iderudit/1014475ar

DOI : https://doi.org/10.7202/1014475ar

Aller au sommaire du numéro

\section{Éditeur(s)}

Canadian University Music Society / Société de musique des universités canadiennes

\section{ISSN}

0710-0353 (imprimé)

2291-2436 (numérique)

Découvrir la revue

Citer cet article

McClatchie, S. (2000). Theory's Children; or, The New Relevance of Musicology. Canadian University Music Review / Revue de musique des universités canadiennes, 21(1), 14-27. https://doi.org/10.7202/1014475ar

\section{Résumé de l'article}

The recent theoretical turn in musicology has made the discipline more relevant, both within the university itself, and in the larger society within which it is situated. I consider what this development may mean for younger scholars, both as graduate students and as new faculty members, and explore the paradox that critical theory is often attacked for its impenetrability, yet has allowed us to communicate more easily with our colleagues in other disciplines. Finally, I argue that the primary aim for music study in the twenty-first century should be an ethical one: the creation of whole, musical human beings, literate in, and accustomed to thinking about, musics, plural, rather than Music.
All Rights Reserved @ Canadian University Music Society / Société de musique des universités canadiennes, 2000
Ce document est protégé par la loi sur le droit d'auteur. L'utilisation des services d'Érudit (y compris la reproduction) est assujettie à sa politique d'utilisation que vous pouvez consulter en ligne.

https://apropos.erudit.org/fr/usagers/politique-dutilisation/ 


\title{
THEORY'S CHILDREN; OR, THE NEW RELEVANCE OF MUSICOLOGY ${ }^{1}$
}

\author{
Stephen McClatchie
}

\section{Musicology is stiff from centuries on its knees in front of the icons of Genius. ${ }^{2}$}

At the outset I ask the reader to forgive the perhaps excessively autobiographical nature of this contribution, but it seems presumptuous for me, at this stage in my career and experience, to try to speak for the discipline, or even its. Canadian branch, as a whole. I might take comfort in the fact that, as the old feminist saw goes, the personal is political-or in this case, perhaps, disciplinary. My aim in what follows is threefold: I want to consider what the theoretical turn in musicology has meant for younger scholars, both as graduate students and as new faculty members; second, I want to examine what De Man termed the "resistance to theory" as seen in the discourse around ideas of specialization and disciplinarity as they relate to the humanities in general and advanced music study in particular; ${ }^{3}$ and finally, I hope to link these two in a consideration of curriculum and pedagogy. I should state at the outset that this paper will probably raise more questions and issues than provide answers or prognostications for the future; it will, however, conclude with a plea for relevancy and wholeness, which, if anything, is my hope for music study in this new century.

\section{STRUGGLING WITH THEORY}

Regardless of where one stands on the political and/or cultural spectrum(s), it is clear that music study has changed extensively during the past twenty or twenty-five years. It is customary to focus on the publication of Joseph Kerman's influential Contemplating Music in 1985 as a significant watershed in the history of musicology, which of course it was, but it is worth keeping in mind that new directions were already underway by that time. ${ }^{4}$ Topics such as nineteenth-century Italian opera, American musical theatre, or Victorian parlour songs have now become acceptable areas of inquiry, and our conference

1 I wish to thank Lynn Cavanagh, David Garneau, and Christine Ramsay for helpful comments and suggestions after reading earlier versions of the paper.

2Robert Fink, "Elvis Everywhere: Musicology and Popular Music Studies at the Twilight of the Canon," American Music 16 (1998): 167.

3 Paul de Man, The Resistance to Theory (Minneapolis: The University of Minnesota Press, 1986).

4Joseph Kerman, Contemplating Music: Challenges to Musicology (Cambridge, Mass.: Harvard University Press, 1985). 
programs and journals are brimming with papers that our fathers and grandfathers-I use the masculine construction deliberately-would have deplored, to say the least. Probably the most significant, and most contested, change has been the importation of models taken from that interdisciplinary body of knowledge known as critical theory. ${ }^{5}$

Like many scholars my age, I was first exposed to theory as a graduate student-largely, but not exclusively, at my own initiative. It was an exciting time, one of rapidly expanding intellectual horizons, both my own and, it seemed to me, those of the discipline too. An important forum for debate and the dissemination of many of these ideas was the unofficial electronic discussion forum of the American Musicological Society, the ams-list. 6 There, articles, papers, and issues were discussed and debated with fervour and passion; certainly tempers did at times run high, but for the interested (proto-) musicologist, it was a stimulating source of bibliographical minutiae and fascinating glimpses at areas and issues I had never considered before.

As I became conscious of it, and active in it, the field of musicology - or at least those areas in which I was interested - seemed one of endless controversy and reaction. For example, 1991 saw the publication of Susan McClary's collection of essays, Feminine Endings: a lightning rod for many of the changes that musicology was undergoing. ${ }^{7}$ I was present as McClary was attacked at local and national meetings and in graduate seminars, and was scandalized by Pieter van den Toorn's notorious attack on her in the Journal of Musicology (and cheered by Ruth Solie's wonderful rebuttal in the next issue, which I devoured in page proof, standing at the University of California Press booth at an AMS meeting). ${ }^{8}$ Likewise, these were the years of the Schubert sexuality debate (by which, as a gay man, I was alternately bemused and appalled); ${ }^{9}$ and

5I will not rehearse this burgeoning literature here; for overviews, see, for example, Joseph Kerman, "American Musicology in the 1990s," Journal of Musicology 9 (1991): 131-44; the Alternative Musicologies issue of the Canadian University Music Review (no. 10/2 [1990]); the Approaches to the Discipline issue of Current Musicology (53 [1993]); Nicholas Cook, Music: A Very Short Introduction (Oxford: Oxford University Press, 1998); and Nicholas Cook and Mark Everist, eds., Rethinking Music (Oxford: Oxford University Press, 1999).

6I am referring to the "old" ams-list, now known as the m-list, run from the University of California at Davis. In August 1998, an official, moderated electronic discussion list, likewise called the ams-list, was established by the AMS at the University of Virginia. Although the old list continues to be active, neither list is as lively as the old ams-list was in the early 1990s.

7 Susan McClary, Feminine Endings: Music, Gender, and Sexuality (Minneapolis: University of Minnesota Press, 1991).

8 Pieter C. van den Toorn, "Politics, Feminism, and Contemporary Music Theory," Journal of Musicology 9 (1991): 275-99; Ruth Solie, "What Do Feminists Want? A Reply to Pieter van den Toorn," Journal of Musicology 9 (1991): 399-410.

9 Important texts in this debate, which was widely reported in newspapers such as the Globe \& Mail and the New York Times, and in the gay and lesbian press, include the following: Maynard Solomon, "Franz Schubert and the Peacocks of Benvenuto Cellini," 19th-Century Music 12 (1989): 193-206; Susan McClary, "Constructions of Subjectivity in Schubert's Music," in Queering the Pitch: The New Gay and Lesbian Musicology, ed. Philip Brett, Elizabeth Wood, and Gary C. Thomas (New York: Routledge, 1994), which was first presented in 1990 and published in the Newsletter of the Gay and Lesbian Study Group of the American Musicological Society 2/i (1992): 8-14; the Schubert: Music, Sexuality, Culture issue of 19th-Century Music 17 (1993), with articles by Rita Steblin, Maynard Solomon, Kristina Muxfeldt, David Gramit, Kofi Agawu, Susan McClary, James Webster, and Robert S. 
the seemingly endless discussion of "New Musicology." 10 If nothing else, it was intellectually exciting.

It soon became clear that many people in the field had strongly visceral responses to these debates. Some professors would brook no mention of anything to do with gender, or sexuality, or race, or whatever, in class, arguing that it was "irrelevant" to The Music Itself. ("You're on a slippery slope," they admonished.) Still others eagerly sought to read and learn about these new developments, even if they did not agree with how the field was developing. At the University of Western Ontario, some graduate students (of which I was one) and professors formed a summer reading group (ARG, the Alleged Reading Group) and ploughed through a lot of material, to widely differing reactions. Given these varying and strongly felt reactions, it certainly seemed sometimes that more was at stake than musicology. For me, this point was driven home by a famous Viennese pianist and scholar standing up at an AMS meeting and almost tearfully denying that Schubert could possibly have been (sob, gasp) a homosexual. How personal it all seemed to be.

Indeed, the turn to the personal has been characteristic of much recent scholarship on both sides of the ideological divide. Later, such personal reaction lead me to write about Britten's terrifying Owen Wingrave, an opera to which I had an immediate and personal response to the issues of closeting and coming out explored therein. ${ }^{11}$ Still later, during a conversation with an eminent British musicologist over dinner, I began to recognize and articulate an increasing discomfort with the often entirely uncritical nature of such "personal musicology," i.e., that it is impossible to gainsay or argue with another scholar's personal experience or insight, so any criticism or dialogue with the work is foreclosed at the outset. ${ }^{12}$

But what does all this have to do with theory? Simply that theory was the binding force behind most, if not all, of these new developments. In other words, for me, and probably for many others of my generation, theory first

Winter; Christoph Schwandt, “'Unaussprechlich, unbegriffen': Indizien und Argumente aus Leben und Werk für die wahrscheinliche Homosexualität des Franz Peter Schubert," in Franz Schubert "Todesmusik," ed. Heinz-Klaus Metzger and Rainer Riehn (Musik-Konzepte 97/98), 112-94; Rita Steblin, "Schubert's 'Nina' and the True Peacocks," The Musical Times 138 (1997): 13-19; Marie-Elisabeth Tellenbach, "Psychoanalyse und historische-philologische Methode: $\mathrm{Zu}$ Maynard Solomons Beethoven- und Schubert-Deutungen," Studien zur italienisch-deutschen Musikgeschichte. Analecta Musicologica 30 (1998): 661-719; and Philip Brett, "Piano Four-Hands: Schubert and the Performance of Gay Male Desire," 19th-Century Music 21 (1997): 149-76.

10Culminating, perhaps, in the session at the 1997 meeting of the International Musicological Society in London, where, by seemingly common consensus, judging by the applause with which the proposal was received, it was agreed to stop using the term. Certainly the debate seems to have lessened since that time.

11 Stephen McClatchie, "Benjamin Britten, Owen Wingrave and the Politics of the Closet; or, 'He Shall Be Straightened Out at Paramore,"' Cambridge Opera Journal 8 (1996): 59-75. In the published version of the paper, my personal response is only dimly visible, if at all. I should be clear that I am not claiming that my experience was unique in any way. Indeed, I suspect that such inchoate feelings and reactions lie behind most scholars' choices of topics. What is different about much recent work, however, is that these things are explicitly foregrounded in the work itself.

12I hesitate to point fingers directly, because others may have different reactions to articles that seem to me to be uncritical and self indulgent. 
impinged upon my consciousness through musicology itself. Theory came to me; I did not come to it. Indeed it was hard to avoid. For example, as a devoted Wagnerian, I eagerly awaited the publication of Carolyn Abbate's Unsung Voices, only to find that I was unable to grasp large sections of it on my first reading. ${ }^{13}$ Likewise, a respected member of my advisory committee insisted that I needed to read Adorno on Wagner-which I had, of course, but was too embarrassed to tell him that I had understood very little. ${ }^{14}$ At the time there was no formal exposure to theory built into my graduate program, neither, I suspect, is it in many graduate programs still. ${ }^{15} \mathrm{I}$ was fortunate enough to be able to take courses from the University of Western Ontario's interdisciplinary Centre for the Study of Theory and Criticism. This provided me with some much-needed perspective and taught me two important lessons: first, that while structuralism, post-structuralism and/or deconstruction, and such, were new, and hot topics in musicology, they were old hat in most other disciplines; and second, that interdisciplinary work carries with it the danger of dilettantism. An AMS session on music and narrative in which the papers, as good as they were, in fact had almost nothing to do with almost any of the (numerous) approaches to narrative theory that I had studied drove this point home for me very forcefully. 16

Lest this seem idealistic, let me stress that my initial reaction to theory, once the first excitement had diminished somewhat, was one of paralysis. All of a sudden it seemed impossible to write anything because it seemed that everything needed to be contexualized and qualified. From the myriad of approaches and isms-structuralism, poststructuralism, reader-response criticism, reception history, New Historicism, narrative theory, ideology critique, the list goes on-which would I choose, and why? It did not seem so easy or straightforward anymore. After some false starts, eventually I negotiated this impasse and wrote a dissertation informed mainly by New Historicism and ideology critique.

Once I reached the other side of the Ph.D. and was lucky enough to find a job, "theory paralysis" emerged once again, less strongly this time, certainly, but still no less disconcerting. Now the question was one of practicality: How does one "do theory" in the real world? It is one thing to deconstruct the idea(l) of the bourgeois subject posited by a Beethoven symphony or a Haydn string quartet, for example, or unpack the anti-Semitic representation of several characters in Wagner's Der Ring des Nibelungen, but quite another to have to write a syllabus for a large, undergraduate class on romanticism, or twentieth-

13Carolyn Abbate, Unsung Voices: Opera and Musical Narrative in the Nineteenth Century (Princeton: Princeton University Press, 1991).

14 Theodor W. Adorno, In Search of Wagner, trans. Rodney Livingstone (London: Verso, 1991).

15 In today's society, when universities are increasingly in the thrall of market-driven, business-oriented approaches to higher education, it is naive, if not downright dangerous, not to change with the times. Graduate programs have a moral responsibility to provide their students with the tools that they need for a solid foundation in the discipline, and these days this must include an exposure to critical theory, as well as Schenkerian analysis, source studies, and other traditional approaches.

16Major approaches to narrative theory are surveyed in my "Narrative Theory and Music; or, The Tale of Kundry's Tale," Canadian University Music Review, no. 18/1 (1997): 1-18. 
century music. There are only thirteen weeks. What do you leave out? Or, to reformulate the question at once more precisely and more broadly, what are the moral and ethical responsibilities of a music professor at the turn of the millennium? I will return to this issue in a moment.

I have adopted a confessional mode in these reflections because I am convinced that my reactions were neither unique nor uncommon. In fact, the vertiginous effects of theory, and musicology's concomitant paradigm shift, were and perhaps still are profoundly disconcerting for many scholars in the field, and it is entirely understandable that some preferred to try to ignore the entire business and get on with their sketch studies or Schenker graphs as if nothing had changed. But in my experience, students are hungry for the insights that theory can provide, even if at times they question or even resist its language. Why? Because in musicology, theory equals relevance.

\section{The UNHElPful JaRgon OF SPECIAlization, Disciplinarity, AND INTERDISCIPLINARITY}

Before pursuing this line of thought, it is worth pausing to situate the rise of theory, and the resistence to it, in musicology against wider university and societal pressures. A common argument against teaching theory at the undergraduate (or even graduate) level is that it is overspecialized-a common reproach made against the humanities in general. Implied in this reproach is that theory, or the humanities as a whole, is/are irrelevant-that is, uninteresting or unimportant to a majority of people. Specialization has often been used interchangeably with disciplinarity, a term which itself has been reconfigured in theory's wake and juxtaposed with interdisciplinarity in a now firmly entrenched false opposition. Upon examination, however, these terms prove to be so loaded as to be unhelpful.

Specialization has both positive and negative connotations in society and academia. On the positive side, it implies competence and expertise: we are referred to specialists for our particular physical ailments; our increasingly technologized world requires ever more specialized technicians to keep it functioning. It is often seen as a good thing, as, for example, in one response to the Federal Government's announcement of the 21 st Century Chairs in the Speech from the Throne in October 1999: "It's going to make universities strong in areas where they're already strong. ... There will be a slow evolution towards specialization." 17 On the other hand, there is the famous G. K. Chesterton comment that "the specialist ... is someone who knows more and more about less and less; he is heading for the eschatological extreme where he will know everything about nothing."18 It is the academic specialist in particular who is singled out for derision; presumably we want our heart surgeons to be

17 Cited by Peggy Berkowitz, "Chairs will strengthen research," University Affairs, December 1999, 24.

18Despite my best efforts, I was unable to find the original source for this quotation. I cite it as formulated in Liora Salter and Alison Hearn, Report to the Social Sciences and Humanities Research Council of Canada on Interdisciplinary (November 1991), 73. 
specialized, likewise our computer technicians. Why the derision in the former case? I suppose that it has to do with the question of utility.

Rhetoric is central to the issue in all contexts: how is the term used, and by whom? In academia, sometimes specialization is seen as opposite to "core" or "general" courses. At the University of Regina, for example, the President recently suggested that "perhaps we can speak of ourselves as having a base in the liberal arts and sciences, together with specialized and professional programmes." 19 Yet it can also carry with it certain proprietary implications, as in a cartoon that appeared in the Chronicle of Higher Education: as two greying professors-male, of course-settle in for another session of papers at yet another conference, one turns to the other and says, "Wake me if he mentions my stuff." While this concept of specialization-as-turf can be politically useful to ward off attacks from conservative colleagues ("this is my area, I know what is best"), it can just as easily be used to impede change ("this is my area, I know what is best").

The reproach of specialization often functions like what Adorno referred to as jargon; it "sees to it that what it wants is on the whole felt and accepted through mere delivery, without regard to the content of the words used." 20 It is a polysemous word. For example, the argument that women's studies or GLBT programs are "too specialized" is hardly politically neutral. Gerald Graff is perhaps the most cogent advocate of this view, arguing that the

common assumption that the academic humanities are narrowly specialized ... has been becoming less and less true for some time. If the academic humanities are over-anything, they are overgeneralized, not overspecialized. ... [O]nce the word "specialized" is used to mean "having a political agenda," it not longer means "obscure" or "narrow," quite the opposite. What is offensive about feminism and ethnic studies is their aggressively general claims about culture, not their pedantic narrowness. ${ }^{21}$

Even in less politicized contexts, the term is not neutral.

Very often the reproach of specialization reveals a covert fear of its loss. This has been especially true in musicology, where models taken from literary theory have been particularly contested. Roger Parker, for example, writes of "our fear that literary studies might 'invade' our discipline, [and] make us become too much caught up in the web of words, too separate from the 'pure' experience of The Music Itself." 22 A recent president of the American Musicological Society argued for the deleterious effects of such paradigms on students trying to prepare themselves for an ever-contracting job market:

19David T. Barnard, Shaping Our Future: Academic Planning Toward the Second Quarter Century,

28 October 1999. Available on the University of Regina Web site at http://www.uregina.cal presoff/issues/AcademicPlanning/index.html.

20Theodor W. Adorno, The Jargon of Authenticity, trans. Knut Tarnowski and Frederic Will (Evanston, Ill.: Northwestern University Press, 1973), 8.

21 Gerald Graff, "Academic Writing and the Uses of Bad Publicity," South Atlantic Quarterly 91 (Winter 1992): 7-8.

22Roger Parker, "Round Table II: Literary Studies: Caught up in the Web of Words" (16th International Congress of the International Musicological Society, London 1997), in Acta Musicologica 69 (1997): 14. I hasten to add that this is not Parker's own position. 
Not only are most of our students inadequately prepared for such positions [requiring a multiplicity of competencies], but some of our very best students, those who have chosen the route of deep specialization, who are doing excellent, original work in a single, complex field of Western art musicwhich they have mastered by means of advanced language training, paleography, analysis, sketch study, archival research-find themselves out in the cold, unemployed. This, I believe is a real crisis. ${ }^{23}$

But scholars on the other side of the methodological divide typically turn around and argue that the valorisation of Rosand's areas of "deep specialization" is exactly what is wrong with musicology today:

Musicology has reached a state of political crisis, despite the best efforts of many musicologists to design a field that was immune to the vagaries of politics, ideologies, and the insistence of numerous Others to experience music differently. ... [I]t is because musicology has insisted on its apolitical status-call it positivistic, call it value-free, call it aesthetically independent-that the field has come face-to-face with its own political acts ... This act of essentializing music, the very attempt to depoliticize it, has become the most hegemonic form of politicizing music. ${ }^{24}$

Here we find "specialization" being used as a club by both sides caught up in our latter-day querelle between the moderns and the postmoderns, as Rosand eloquently put it. ${ }^{25}$

In many instances, "specialization" is used interchangeably with "discipline." Indeed, James R. Davis defines a discipline as a "subject specialization in the arts and sciences; a broader definition ... would include the specializations that also occur within professional fields." ${ }^{26}$ Most academic disciplines arose in the last decades of the nineteenth century, alongside the development of departmental organization in universities, the growth of graduate programs, and the foundation of disciplinary associations:

The most important thing that happened, both in the development of the professions and of the disciplines, is specialization. The unified curriculum of the "liberal disciplines" of the colonial college became the fragmented curriculum of the specialized subjects of the disciplines and professions. Specialization did not end with the discipline; it continued into sub-disciplines and highly specialized areas of scholarly inquiry. ${ }^{27}$

Guido Adler's influential 1885 tabular presentation of the field of musicology is one familiar example of this tendency. As is well known, Adler divided the

23Ellen Rosand, "The Musicology of the Present," remarks delivered at the conclusion of the Society's Annual Business Meeting in Minneapolis on 29 October 1994, published in the AMS Newsletter 25 (February 1995): 10-11, 15; here 11.

24 Philip V. Bohlman, “Musicology as a Political Act,” Journal of Musicology 11 (1993): 419.

25Rosand, "The Musicology of the Present," 11.

26 James R. Davis, Interdisciplinary Courses and Team Teaching: New Arrangements for Learning (Phoenix: American Council on Education and the Oryx Press, 1995), 4.

27Davis, Interdisciplinary Courses, 30-31. 
field into two large subdisciplines, historical musicology and systematic musicology, each of which was further divided into several primary specialities and a number of ancillary disciplines [Hilfswissenschaften].$^{28}$ But although disciplinarity began as a "reasonable effort to delineate domains of study and methods of investigation," the rapid explosion of knowledge in the past century has resulted in the seemingly "infinite regress of specialization." 29 Unlike when Adler wrote, it is impossible today for one scholar to know the whole field of musicology. There are fewer general histories of music written now; indeed, period histories are becoming rather rare. Instead we have detailed monographs and articles delving into seemingly arcane byways and side streets.

Isolation and narrowness are often the unfortunate results of the increasing specialization of disciplinarity. Disciplines tend to develop ever more specialized languages, which make it hard to communicate with scholars in other disciplines, and these languages are often hard to teach beginners, which forces a split between teaching and research. The rigorous scientific language of modern musical theory and analysis comes to mind immediately; indeed the rise of the music theorist (as opposed to the composer, traditionally assigned to teach harmony and analysis in universities) is symptomatic of such disciplinary development. ${ }^{30}$ As Jim Samson writes, the ethos of professionalism which pervades academia has "promoted esoteric languages which often seem expressly designed both to unite the communities of individual disciplines and to separate them from those of other disciplines, and of course from 'mass culture." 31

In recent decades the whole notion of discipline has come under scrutiny. The most influential model here is that of Michel Foucault, who defined discipline as "a type of power, a modality for its exercise," and wrote of it as producing "subjected and practiced bodies, 'docile' bodies." 32 In the words of Stanley Fish, "disciplines are not natural kinds. They emerge in the wake of a political construction of the field of knowledge." 33 Such a view of disciplinarity has played a significant role over the last decade in musicology's internal turmoil over the rise of theory. ${ }^{34}$ The reproach of specialization, however,

28Guido Adler, "Umfang, Methode und Ziel der Musikwissenschaft," Vierteljahrsschrift für Musikwissenschaft 1 (1885): 5-8, 15-20. Available in a slightly abridged English translation by Martin Cooper in Bojan Bujić, ed., Music in European Thought, 1851-1912 (Cambridge: Cambridge University Press, 1988), 34-55.

29Davis, Interdisciplinary Courses, 35.

301 am conscious that I am speaking very generally here. Certainly, many music theorists are conscious of, and trying to negotiate, this linguistic opacity by situating their discourse within a wider context. See, for example, work by Scott Burnham, Fred Maus, Patrick McCreless, Brian Heyer, Nicholas Cook, and others. I am also assuming, perhaps erroneously, that music theory as a discipline aligns itself-or should-with the humanities instead of with the sciences or social sciences. 38.

$31 \mathrm{Jim}$ Samson, "Analysis in Context," in Rethinking Music, ed. Nicholas Cook and Mark Everist,

32Michel Foucault, Discipline and Punish: The Birth of the Prison, trans. Alan Sheridan (New York: Random House, 1979), 215, 138.

33 Cited without reference in Fields and Boundaries: The Shifting Space of Disciplinarity, ed. Judith Herz (Ottawa: Canadian Federation for the Humanities, 1994).

34 It is most cogently discussed in and exemplified by Katherine Bergeron and Philip V. Bohlman, eds., Disciplining Music: Musicology and Its Canons (Chicago: University of Chicago Press, 1992). 
encompasses and transcends both traditional and reconfigured disciplinarity, as well as their supposed antithesis, interdisciplinarity.

Within this traditional view, disciplines are erroneously seen as ineluctably hidebound and reactionary when in fact they develop and reconfigure themselves all the time. Julie Thompson Klein has pointed out the "oversimplified dichotomy" that arises when disciplinarity and interdisciplinarity are used as simple opposites to one another, as if one could not be both disciplinary and interdisciplinary (as I would consider myself). ${ }^{35}$ In fact, some theories of interdisciplinarity insist that it is entirely dependent on disciplinarity, even going so far as to emphasize the need for specialization in any interdisciplinary context. ${ }^{36}$

In short, then, all three of these terms (specialization, disciplinarity, interdisciplinarity) have come to function as jargon, in Adorno's sense. It does not matter where one is situated on the political and cultural-political spectrums, jargon gets in the way of debate and masks the true issues. I would argue that conceiving of musicology's turn to theory in these terms is ultimately unhelpful, and propose instead that we focus on the idea of relevance.

\section{DoING THEORY IN THE REAL WORLD}

By now it should be clear that I regard the rise of theory as, on the whole, A Good Thing. I do think that the theoretical turn has had a salutary effect on the discipline. It has at last given musicologists a language with which to communicate with our colleagues in other disciplines, and has helped to alleviate the seemingly opaque barrier of musical notation for those unable to read it, by giving rise to a discourse in which quoting musical notation is not necessary. My earlier recourse to the rigorous, scientific language of modern music theory and analysis as an example of the dangers of disciplinary narrowness may seem disingenuous, since critical theory is also notorious for its opacity and difficulty. ${ }^{37}$ Yet, it is a language that many people speak, and increasing numbers of scholars from outside the discipline are now writing about music in sophisticated and exciting ways. ${ }^{38}$ It can only benefit all of us if our subject is seen

35 Julie Thompson Klein, Interdisciplinarity: History, Theory and Practice (Detroit: Wayne State University Press, 1990), 105.

36For example, Donald Campbell's "fish-scale theory" of interdisciplinarity. Campbell envisions the interdisciplinary field as consisting of many overlapping specializations working together in a collective fashion; see Liora Salter and Alison Hearn, Report to the Social Sciences and Humanities Research Council of Canada on Interdisciplinary (November 1991), 67-69.

37 A good example of this may be found within the pages of this very journal: after I had seen the page proofs for my article on narrative theory ("Narrative Theory and Music"), a conscientious editor quite innocently corrected my supposed misspelling of "différence" when I was actually referring to Jacques Derrida's notion of différance. Once this misprint was pointed out, I was generously given an opportunity in the next issue to correct the correction ("Corrigendum," Canadian University Music Review, no. 18/2 [1998]: ii).

38For example, Linda Hutcheon and Michael Hutcheon, Opera: Desire, Disease, Death (Lincoln: University of Nebraska Press, 1996); Edward Said, Musical Elaborations (New York: Columbia University Press, 1991); Susan J. Leonardi and Rebecca A. Pope, The Diva's Voice: Body, Voice, Prima Donna Politics (New Brunswick, N.J.: Rutgers University Press, 1996); and contributions by non-musicologists in two collections on opera: Corinne E. Blackmer and Patricia Juliana Smith, eds., En 
as significant, and relevant, within wider historical and cultural circles-not only as an aesthetic object, or as an escape "in eine bess're Welt," but as an important historical agent in its own right. My closest intellectual (as opposed to musical) bonds at my university are with my academic colleagues in film and video, theatre, and visual arts, and these bonds have been forged through the common language of theory. Together, one of us from each discipline, we teach an interdisciplinary first-year course entitled "Fine Arts and Ideas: Hamlet's Ghosts" that introduces students to the main ideas and concepts of various theoretical approaches, using Hamlet as a peg on which to hang this theoretical garb.

A central theoretical tenet revolves around the mutually transformational nature of our encounters with Others. ${ }^{39}$ For musicology, theory was, in many respects, such an Other, and there is no question that musicology has changed since the two began flirting. I hope that as musicologists continue to engage with theory, our work will also have an effect on theory itself, as it is practised in other disciplines. For example, sophisticated work, like Carolyn Abbate's on voice, ought to have an impact on both literature and film scholars. ${ }^{40}$

For music, which (so far) seems to have avoided the worse excesses of theory as practised in many English departments, theory has been a process, or tool, to an end, rather then an end in itself. It has been a tool to the reintegration of music into the wider discourse of the humanities, a reintegration that has revealed the relevance of music and music study to broader socio-cultural concerns. Through theory, then, it is my hope that music can partake of what may be the beginning of better days for the humanities in Canada: a major conference on the humanities sponsored by the Social Sciences and Humanities Research Council of Canada (SSHRC) in the fall of $2000 ; 41$ a recognition of the value of a humanities education within the new knowledge-based economy; ${ }^{42}$ and, finally, a recognition that humanities graduates are not necessarily economically disadvantaged with this new economy. ${ }^{43}$

travesti: Women, Gender Subversion, Opera (New York: Columbia University Press, 1995), and Richard Dellamora and Daniel Fischlin, eds., The Work of Opera: Genre, Nationhood, and Sexual Difference (New York: Columbia University Press, 1997).

39Gary Tomlinson, Music in Renaissance Magic: Toward a Historiography of Others (Chicago: University of Chicago Press, 1993).

40 Abbate, Unsung Voices; idem, "Debussy's Phantom Sounds," Cambridge Opera Journal 10 (1998): 67-96; idem, "Outside Ravel's Tomb," Journal of the American Musicological Society 52 (1999): 465-530.

41 Alternative Wor(l)ds: The Humanities in 2010, 19-21 October 2000, The University of Toronto.

42 As witnessed by the increasingly frequent statements by CEOs affirming the value of a humanities education. See John Partridge, "High-Tech CEOs Voice Support for Financing Liberal-Arts Studies," Globe \& Mail, 8 April 2000, A5; Peter C. Godsoe, "In Defence of Liberal Arts," Western News, 15 June 2000, 9; Paul Davenport, "The Liberal Arts in the Knowledge Society," University of Toronto Convocation Address, delivered 19 June 2000. Available at http://www.uwo.ca/pvp/honors/faculty/ hondegrees/pres1.htm.

43 Robert Allen, "The Employability of University Graduates in the Humanities, Social Sciences, and Education: Recent Statistical Evidence." Report prepared for SSHRC, August 1998. See Richard Mackie, "A Report Questions Growing Bias Toward High-Tech Studies," Globe \& Mail, 6 December 1999, A18. 
The SSHRC Working Group on the Future of the Humanities, of which I am a member, has drawn up a statement on the humanities that aims to inform outsiders what it is that we do, and, more importantly, to articulate its value in terms of the transferrable skills our graduates (should) possess: communication skills (reading, writing, electronic communication); the ability to interpret "complex instances of human expression" and "make interconnected relationships between ideas, thereby encouraging the kind of intellectual flexibility demanded by today's knowledge economy"; a capacity for analysis and synthesis, as well as other generic problem-solving techniques ("Statement on the Humanities," version dated 18 November 1999). It is likely that this statement, at this point circulated largely within SSHRC itself, will form a part of a public report on the humanities, forthcoming from the Working Group.

By way of conclusion, I want to consider how what I have called the new relevancy of music might affect its advanced study. My own undergraduate teaching has certainly been informed by theory. Although I tend not to use theoretical terminology rigorously in class, many of theory's presuppositions. underlie my basic approach to music history. In my view, music history is not simply the study of music composition, it is the study of music itself: what it means in and to any given society; its role and that of its composer in society. If I had to sum up my approach to teaching music history, I might propose a something like this:

A responsible music history course cannot consist only of dates and facts and structural analyses of pieces. It must also teach students to consider how and what a piece of music might mean in its social and cultural contexts at the time of its composition, and as it travels throughout history.

In planning classes, I try to move beyond the traditional paradigm of surveying one Great Composer and His (never her) Masterworks after another by-for example-arranging classes by genre and making a point of including works by women and "second-tier" composers. I also try to discuss the posthumous careers of composers and their works to introduce students to the idea that composer reputations wax and wane, and that their meanings are never stable, but are always in flux and influenced by present-day conditions.

To speak more generally, though, I think that it is our ethical and moral responsibility to problematize for students the whole idea of die Musik. ${ }^{44}$ Instead, we should expose students to a whole range of musics and possible contexts for music: music as an object; music as a process; music as remarkable or unremarkable; music as a signifying process; music as a constructor of identity. ${ }^{45}$ This is not to say that our courses should be balkanized out of recognition; indeed what I am proposing does not require that we all suddenly jettison seventeenth-century Italian cantatas from our curriculum in favour of

44I borrow this formulation from Philip V. Bohlman, "Ontologies of Music," in Rethinking Music, ed. Nicholas Cook and Mark Everist, 25-26.

45See Bohlman, "Ontologies of Music" and idem, "Viewpoint: On the Unremarkable in Music," 19th-Century Music 16 (Fall 1992): 203-16. 
rap or boy bands. Not everyone is interested, or able to do that. It does require that we be explicit about what it is that we teach, and why. An important benefit of such an approach is that it allows us to address popular music and culture, even if they are not our primary interests. Most of us teach in departments devoted to one particular musical practice, the art music of (much of) the West. It is unconscionable now to pretend that this music is the only music that matters, even if it is the only music that does matter to us. (I often find myself arguing this position with my colleagues-ironically, since I myself have very little interest in most popular musics. I also have very little interest in Boulez, Babbitt, and their ilk, but I teach them nevertheless.)

We need to instill in our students a consciousness of the fictiveness of scholarship and pedagogy, in the sense of the Latin verb fictio, to make or construct something. One way of doing this is to remind them of the silences in our courses-what it is that we don't teach, what we have left out. ${ }^{46} \mathrm{We}$ should also situate concepts like Genius, masterpiece, and such, so that they no longer appear as neutral, or natural terms. ${ }^{47}$ This does not mean that we cannot, or should not, use them-a romantic-period course arranged around Great Men may in fact be the most historically correct way to present the material, but we need to be explicit about why we have organized the material in this fashion. In the words of one recent commentator,

We teach more effectively, more truly, if we try to restrain a tendency to promote our own solutions to various questions about music, and instead teach methods of examining such questions. ${ }^{48}$

It is thus important to teach disciplinary archeologies to our students at both the graduate and undergraduate levels. ${ }^{49}$ And they seem to really enjoy it, at least in my experience!

The study of performance should be more integrated into the study of music history than it often is. As José Bowen has argued, performance study provides (and reveals) the link between history (changing performance practices) and hermeneutics by exploring "the history of the changing definition of the work itself." 50 It thereby helps to lessen genuflection before The Work or The Music, Itself, and reformulates the authoritarian, single-author model, focussed solely

46Ralph Locke, "Musicology and/as Social Concern: Imagining the Relevant Musicologist," in Rethinking Music, ed. Nicholas Cook and Mark Everist, 523.

47Christine Battersby, Gender and Genius: Towards a Feminist Aesthetics (London: The Women's Press, 1989). For a deconstruction of the "natural," see Linda Nochlin, "Why Have There Been No Great Women Artists?" in Women, Art, and Power and Other Essays (New York: Harper \& Row, 1988), 145-78.

48Locke, "Musicology and/as Social Concern," 524.

49 This a project that has only recently been undertaken in music. See, for example, Katherine Bergeron, Decadent Enchantments: The Revival of Gregorian Chant at Solesmes (Berkeley and Los Angeles: University of California Press, 1998) and Pamela M. Potter, Most German of the Arts: Musicology and Society from the Weimar Republic to the End of Hitler's Reich (New Haven and London: Yale University Press, 1998).

50José Bowen, "Finding the Music in Musicology: Performance History and Musical Works," in Rethinking Music, ed. Nicholas Cook and Mark Everist, 430, 450. 
on the composer, into a more humane and egalitarian one of multiple authors (composer, performer, listener)..$^{51}$

Teaching such concepts to our students can only serve to make advanced music study more relevant for them, and more integrated with the society in which they live. The past several decades have seen higher education become much more common and available, resulting in the entry of other groups into the academy: people of different classes, ethnic and racial backgrounds, etc.; women; and openly gay or lesbian students. ${ }^{52} \mathrm{We}$ do them a disservice not to acknowledge and address their difference, to continue to write and teach about "our" music and "our" history in a way that may exclude more than it includes. While some have deplored such views as amounting to the politicization of music (or the humanities as a whole) by theory, I would argue that they really mark its increasingly relevance within wider social, cultural, and political spheres. ${ }^{53}$

For me, the pressing issue is the development of our students as whole musical human beings, able to negotiate between the different musics that they may encounter. I want to help my students overcome, or at least acknowledge, the schizophrenic split that I see in many, if not most, students today: studying and learning to play Western art music, but never or seldom listening to any. In my estimation, music history is one of the most important subjects for music students because it provides a context within which to evaluate and understand the works that they perform or encounter. Thus my final plea, and hope for advanced music studies in this new millennium, is one for wholeness and inclusion: of the student as a performer, of the student and professor as human beings in a wider society, with ethical and moral responsibilities to themselves and to each other.

\section{Abstract}

The recent theoretical turn in musicology has made the discipline more relevant, both within the university itself, and in the larger society within which it is

51 Such formulations draw on Roland Barthes's well-known distinction between "work" and "text," see "From Work to Text," in Image-Music-Text, trans. Stephen Heath (New York: Noonday Press, 1977).

52Racial and ethnic elements have yet to make an impact upon the discipline, largely because of the discipline's principal focus on the art music of the West. Still, the influence of Edward Said's Orientalism (New York: Pantheon, 1978) has been significant; see, for example, Jonathan Bellman, ed., The Exotic in Western Music (Boston: Northeastern University Press, 1998). See also Lawrence Kramer, "Powers of Blackness: Africanist Discourse in Modern Concert Music," Black Music Research Journal 16 (1996): 53-70; Leo Treitler, "Toward a Desegregated Music History," Black Music Research Journal 16 (1996): 3-10. Within the field of popular music studies, of course, these concerns are more central; see, for example, Tricia Rose, Black Noise: Rap Music and Black Culture in Contemporary America (Hanover, N.H.: University Press of New England, 1994). Adam Krims, Rap Music and the Poetics of Identity (Cambridge: Cambridge University Press, 2000) includes a discussion of Canadian Cree rapper, Bannock. Another important contribution is Canadian Music: Issues of Hegemony and Identity, ed. Beverley Diamond and Robert Witmer (Toronto: Canadian Scholars' Press, 1994).

53 Suzanne G. Cusick has written about the importance of such "presentist" responses in her "Re-voicing Arianna (and Laments): Two Women Respond," Early Music 27 (1999): 437. 
situated. I consider what this development may mean for younger scholars, both as graduate students and as new faculty members, and explore the paradox that critical theory is often attacked for its impenetrability, yet has allowed us to communicate more easily with our colleagues in other disciplines. Finally, I argue that the primary aim for music study in the twenty-first century should be an ethical one: the creation of whole, musical human beings, literate in, and accustomed to thinking about, musics, plural, rather than Music. 